\title{
THE EFFECTS OF INTEGRATING MATHEMATICS AND SCIENCE \& SOCIAL STUDIES TEACHING IN LEARNING MATHEMATICS
}

\author{
Milenko Ćurčić, Dragica Milinković ${ }^{2 \star} \&$ Dragana Radivojević $^{3}$ \\ ${ }^{1}$ Prof. Dr., University of East Sarajevo, Bosnia and Herzegovina, ljekobilje@teol.net \\ ${ }^{2}$ Assoc. Prof. Dr., University of East Sarajevo, Bosnia and Herzegovina, sadra@teol.net \\ ${ }^{3}$ Assist. Prof. Dr., University of East Sarajevo, Bosnia and Herzegovina, dragan-r1@live.com \\ ${ }^{*}$ Corresponding author
}

\begin{abstract}
The Primary Education in Bosnia and Herzegovina is still being dominated by the concept of scienceoriented teaching according to which teachers are "forced" to implement relatively strict division of educational areas within even more stringent and divided subjects from the first class. In such circumstances, in mathematics teaching of the basic and developmental cycle of primary school pupils are most often "served" tasks isolated from the authentic context, that they solve mechanically, trailing only algorithmic steps. A problem arises when they face the need for the application of acquired knowledge in the real life situations. This implies that the initial teaching of mathematics predominantly activates students' cognitive area, but in a significant deficit of other psycho-physical areas, which is brought into collision with the basic natural needs of children. Taking into account their strongly expressed need for simultaneous performance of different activities, there is a demand for connecting and integrating scientific and educational areas, both within one subject and between different subjects. Bearing in mind that the natural and social environment represents a starting point and a source on which are based all the cognitions that the child acquires in the elementary grades, the integration of teaching mathematics and teaching science \& social studies imposes naturally.
\end{abstract}

Accordingly, the work deals with the learning of mathematics through the integration of the syllabus contents of science \& social studies. The aim is to help students not perceive mathematics as a set of definitions, axioms, theorems and proofs. In a sample of 278 students aged 8 to 9 years, an experimental research has been carried out in order to examine the effects of an interdisciplinary approach to teaching mathematics and reactions of students to this model of teaching and learning.

All the students have reacted positively to this approach to teaching mathematics, as demonstrated in the results of assessments, suggesting that a multidimensional approach to learning significantly contributes to a better understanding of mathematical contents and concepts and to the better understanding of science \& social studies content. It also remarkably raises the quality of the functional and applicable knowledge and motivation for learning in general.

Keywords: integration of teaching mathematics and science \& social studies, understanding of mathematical contents and concepts, the application of acquired knowledge, motivation to learn mathematics. 


\section{INTRODUCTION}

In the modern classroom teaching many teachers create and implement a number of educational scenarios that enable successful and better learning. The emphasis is placed on the interdisciplinary approach that is much closer to the way the human brain works naturally and it best fits learning in the real life. It highlights intellectual and social, but also emotional and aesthetic component of students' development, which means that the interdisciplinary approach to learning supports holistic development of students, rather than separate, mainly cognitive aspects. The interdisciplinarity of teaching implies the realization of the principle that all elements of the teaching process (contextual, psychological, cognitive, social, organizational) are functionally linked and form a harmonious whole. Linking teaching areas and contents is contemporary and one of the most important strategies in education (CONNECTIVITY AS A NEW LEARNING STRATEGY). From the standpoint of operational objectives and tasks, as well as applicable curricula, few subjects have a high degree of correlation with other subjects. However, the need for integration of teaching depends not only on the degree of correlation of the courses, according to the above mentioned elements, but also on many other factors, primarily psychological and physical characteristics of children. The fact that children of primary school age, especially in the basic and developmental cycle of elementary school, have strongly expressed need for the simultaneous performance of different activities has long been known and proven. If their need is being answered by the linking of teaching contents, the learning motives are thus united, and therefore increased. This is in itself a reason good enough to integrate different learning areas and contents in modern teaching. The reason for the greatest possible use of well-designed and implemented, integrated teaching stands in its ability to achieve complex goals and tasks. This means that, for about the same time spent, better teaching effects are being achieved, in terms of their rationality, purposefulness, students' achievement and sustainability of knowledge.

Many authors have dealt with the conceptual definition and characterization of interdisciplinarity from different scientific points of view, which resulted in the emergence of different interpretations and definitions of terminology. Interdisciplinarity is one of the ways that in investigating and solving a given problem more than one scientific discipline has been used (Meyer, 2007, pp. 203-212). The concept of interdisciplinarity in the older literature is known as a cross-curricular coherence or correlation in teaching, and in the recent literature as an integrated (integrative) teaching. Integrated teaching is the teaching system in which the boundaries between different subjects have been ignored. Through integrated teaching meaningful connections between similar aspects of different disciplines can be achieved. Integration does not mean the renunciation of the discipline itself. Its roots are precisely in separate disciplines. It, however, offers an alternative to the dominance of knowledge from the perspective of the individual disciplines. Individual disciplines offer focus and depth, and integration offers breadth of the context, change of perspective, and application of knowledge from one area to another, that is functional knowledge (Đorđević, 2007, pp. 76-97). Lake (1994) gave us the all-encompassing definition of integrated teaching, stressing that it should be understood as:

- complex research of knowledge from different areas of environmental issues within the reality of students;

- rational move through teaching areas and the integration of various elements in the logical units that realistically reflect the reality of life;

- unique common nodes in the knowledge that encourage students to invent relationships, create models, systems and structures;

- applied methodology and language of more different subjects for research main themes, issues or experiences;

- merging multiple-subject areas in a way that children in everyday reality master objects and phenomena, linking them into a single process;

- a new way of thinking;

- preparation for the application of knowledge in new situations (knowledge transfer) using the adopted cognitive models.

In pedagogical terms, the notion of integrated teaching is primarily referring to the process of knowledge construction in which the problem is being analyzed using different disciplinary approaches, which eventually enables interdisciplinary understanding, integrating knowledge and thinking (Klein, 2006, pp. 10-18). In the integrated teaching the role of teachers is particularly important since teachers are those who apply 
interdisciplinary educational model at the very beginning of educational process in order to make students become aware of the interdependence of all the parts of life (Walsh, 2002).

Within the group of science and social studies subjects there are independent teaching disciplines that are inextricably linked by continuous conceptual and theoretical internal connections. At the same time, they are not isolated from the other school subjects that precede or accompany them in the curriculum for general education and upbringing. The tendency for inter-linking occurs from the need to increase the efficiency of the teaching process in all subjects taught in primary education. The link between school subjects, close by their contents, not only affects the increase in the quality of knowledge but it also helps in preparing students for independent work and affects the formation of a scientific world outlook (Ćurčić, 2006).

Subjects taught in the lower elementary grades provide outstanding opportunities for the application of interdisciplinary forms of teaching and learning, which are, viewed in terms of the objectives of syllabus contents, in some way implicated because they contribute to the formation of authentic, meaningful, developmentally appropriate, life experiences. When it comes to mathematics, the effectiveness of an interdisciplinary approach to the syllabus contents is very high, and it is reflected in the following:

- a holistic approach to the process of acquiring knowledge, ie. formation of mathematical concepts, the adoption of mathematical rules and solving mathematical tasks, primarily problems;

- building of the system of the applicable students' knowledge;

- contributes to the activation and the rationalization of the teaching process;

- creates conditions for the expression of specific potentials that students have;

- provides an opportunity for better ideas, new interests and achieving success;

- enables meaningful, developmentally appropriate, experiential, authentic and lifelong learning;

- opens opportunities for the integration of students' knowledge, skills and habits in a unique interdisciplinary unit that is constantly being transformed (Milinković, 2013, pp. 130-143).

Integrative approach to creating mathematical contents in the lower elementary grades, therefore, emphasizes the connection and simultaneous implementation of the mathematical content with the close, related parts of the contents of other subjects, with the precise differentiation of specific tasks that need to be achieved through specific mathematical content. This way of work contributes to the activation of the teaching process because different types of activities and the related contents in various subjects and teaching topics that are aligned with the interests of students ensure their active participation in the implementation of the mathematical contents. This would create conditions and open possibilities for expression of specific potentials that students have, the opportunity for better ideas, new interests and achieving success, regardless of the differences in the level of mathematical knowledge acquisition among children there.

Classroom teaching of mathematics and general teaching in lower elementary grades, due to their specificities, are suitable for the realization of the model of integrated thematic instruction, given that in this age the problems of everyday life are discussed, which are by their nature often interdisciplinary. In addition, the child's curiosity is accordance with this kind of work since they learn through their own experience and practical examples based on concrete logical operations they have at that age. Thematic integration of teaching content is primarily based on the realization of horizontal correlation of subjects within a school grade aimed at realization of the theme from the natural and social contexts. Integrative approach to planning and implementation of educational content in the lower elementary grades raises numerous issues that the organizers of the educational process encounter (Milinković, 2012, pp. 171-184). The first and the most important issue is the choice, creating and defining the theme as the integrating factor around which, or in which are integrated scientific and educational area of different subjects. Given that the natural and social environment is a starting point and a source on which is based all the knowledge that the child acquires in the lower elementary grades, the contents of the subject Science \& Social Studies, especially those related to certain aspects of the students' immediate environment, provide a useful baseline for the realization of interdisciplinary teaching and learning, ie. are intrinsically linked with all other educational areas and as such represent the thematic framework of integrated teaching. Accordingly, it is logical to conclude that the integration of content in the primary school is to be delivered under three themes - nature, man, society, since the subject has been formed on this basis (Banjac, 2015). Determination of themes for the realization of integrated teaching can be conditioned by the current situation in the region, an event or action in the local community in which the school may be included, or some school classes and individual learners. In theory, all science subjects in primary and secondary schools are methodically designed bases of adequate natural 
sciences. Therefore, their contents reflect the objective relationship that exists in the nature and between the natural sciences. The link between natural sciences and their subjects should be predominantly represented in the cognitive process of learning their syllabus contents. This connectivity allows students to understand the dialectic of nature on the accessible level for them and contributes to thorough acquisition of knowledge (Žderić \& Miljanović, 2001).

Defining goals, definition of expected outcomes, setting tasks to achieve the goal and achieve the outcomes for each theme are the following questions that the organizers of the educational process in the integrated teaching encounter. Aim and outcomes are determined for each subject, while the tasks are being defined for each learning content in the context of the theme. The next question that arises is how to organize the working day, which activities use in order to accomplish the tasks, when and on what syllabus contents simultaneously accomplish educational tasks from different areas, and what contents and how much time to devote to the realization of specific tasks within each subject. Active learning can be achieved when a student actively explores various sources of knowledge, tends to understand studied content, links the new content with the previous knowledge and experience, draws independent conclusions and incorporates them into a personal system of knowledge. In that sense, it is important to use models of active learning (teaching different levels of complexity, educational computer software, seminars, learning through discovery, mind maps) which help us achieve the highest goals of modern teaching, and that is - a student is at the center of the teaching process with the possibility of flexible adopting teaching content and systematic realization of the set objectives (Radivojević, 2014, pp. 91-106). In interdisciplinary teaching, activities are planned from the perspective of students since „an interdisciplinary approach to teaching best suits learning in real life that integrates and connects different areas of development and provides a new quality of learning" (BuljubašićKuzmanović, 2007, pp. 147-160). The order of work on mathematical contents of Science \& Social Studies teaching is the next question that arises in the organization of integrated teaching of Mathematics and Science \& Social Studies, and which is dependent on the functional connections and tasks, methods and forms, places of work, teaching aids, prior knowledge and readiness of students. Specifics of the mathematical contents and science \& social studies contents in an integrated teaching, emphasize work in small groups, which, according to the thematic model of integrated teaching, interpret and solve a given problem within the theme from the aspect of different subjects, and different educational areas. Sometimes there will be a number of activities aimed at accomplishing one task, as well as more tasks accomplished through the same activity. It is essential that the activities allow individual, team and group participation of students in clarifying a set goal. During group work there are particularly favorable affective and cognitive conditions to solve a problem because the group of students "join forces" in solving a problem, even if only one student in the group found the exact solution. When they learn in groups, students have the opportunity to exchange information and opinions, broaden their mental structures to adopt and adapt new concepts. Since groups of students are mainly heterogeneous in terms of gender, level of knowledge, abilities, etc., these differences often lead to the cognitive conflict which is one of the key mechanisms in the development of thinking.

Interdisciplinary teaching and learning of mathematics by experiencing and discovering the natural and social environment or seemingly meaningful situations contributes to the promotion of understanding, both on the conceptual and at the operational level, since the art of applying the acquired knowledge and skills is more useful and beneficial than knowledge of arithmetic and geometry. In this regard, mathematical models that mediate between the authentic context and formal mathematical knowledge are especially important, particularly graphical representations that contribute to the understanding of standard algorithms in the initial teaching of mathematics (Milinković, 2015, pp. 8-24).

\section{RESEARCH METHODOLOGY}

The aim of the research refers to the study of the effects of the interdisciplinary approach to teaching Mathematics and Science \& Social Studies, and the reactions of students to this model of teaching and learning. Considering the complexity of the research objective, this quantitative study has been carried out on a sample of 278 pupils of the third grade of primary school (aged 8 to 9 years) from 4 primary schools in Bosnia and Herzegovina. 139 pupils have formed the experimental group and 139 have belonged to a control group, the two groups being unified according to the success achieved in the initial test. The study applied the pedagogical experiment with parallel groups (an experimental and a control group), where the students of the experimental group implemented contents by using the integrated model of learning, whereas the control group students have realized the contents by using conventional, traditional models of work. It was presumed that the applied model, i.e. a multi-dimensional approach to learning, contributes to a better understanding of mathematical contents and concepts, to the more efficient application of acquired knowledge and to the greater motivation of students for work. 
The experimental program was implemented during school year 2014/2015, as a part of the regular classes, and in the preparation of the experimental program we fully abide by the objectives and outcomes, in order to get the most valid and reliable results.

The applied testing technique is in the form of an initial test and a final test. The initial test is given in order to determine the initial level of knowledge of students in Mathematics and Science \& Social Studies, while the final test is given in order to determine the final degree of students' knowledge after the introduction of the experimental model of work in order to comprehend the efficiency of interdisciplinary and multidimensional approaches in teaching mentioned subjects. The structure of the initial and the final test, which the authors constructed for the research purposes, consisted of 20 tasks (10 in Mathematics and 10 tasks from Science \& Social Studies). Pupils were doing the tasks simultaneously in order to achieve that objective conditions and results, but the results for the purposes of research, have been analyzed individually.

Data have been analyzed by using the statistical software package SPSS 24.0 , where the one-way analysis of variance (ANOVA) has been implemented.

\section{RESEARCH RESULTS AND DISCUSSION}

Before the introduction of the experimental program the initial assessment has been carried out. In the initial test in Mathematics (Table 1) students of the experimental group have achieved an average of 6.410 points, and the students of the control group 6.417 points.

Table 1. The results of the experimental and control groups at the initial test in Mathematics

\begin{tabular}{|c|c|c|c|c|c|c|c|c|}
\hline \multirow{2}{*}{ Group } & \multirow{2}{*}{$\mathrm{N}$} & \multirow{2}{*}{ Mean } & \multirow{2}{*}{$\begin{array}{l}\text { Std. } \\
\text { Dev. }\end{array}$} & \multirow{2}{*}{$\begin{array}{l}\text { Std. } \\
\text { Er. }\end{array}$} & \multicolumn{2}{|c|}{$\begin{array}{l}\text { 95\% Confidence } \\
\text { Interval for Mean }\end{array}$} & \multirow{2}{*}{ Min. } & \multirow{2}{*}{ Max. } \\
\hline & & & & & $\begin{array}{l}\text { Lower } \\
\text { Bound }\end{array}$ & $\begin{array}{l}\text { Upper } \\
\text { Bound }\end{array}$ & & \\
\hline Experimental & 139 & 6.410 & 1.887 & .160 & 6.093 & 6.726 & 2 & 10 \\
\hline Control & 139 & 6.417 & 1.910 & .162 & 6.096 & 6.737 & 2 & 10 \\
\hline Total & 278 & 6.413 & 1.895 & .113 & 6.189 & 6.637 & 2 & 10 \\
\hline
\end{tabular}

From the total score of 1783 points the experimental group won 891 points and the control group won 892 points. From the presented data, the uniformity of the groups at the initial test in mathematics can be seen. The analysis of variance has been calculated in order to determine the statistical significance of the analyzed variables (Table 2).

Table 2. Analysis of variance of the initial test in Mathematics

\begin{tabular}{|c|c|c|c|c|c|}
\hline & Sum of Squares & df & Mean Square & F & Sig. \\
\hline Between Groups & 0.004 & 1 & .004 & .001 & .975 \\
\hline Within Groups & 995.424 & 276 & 3.607 & & \\
\hline Total & 995.428 & 277 & & & \\
\hline
\end{tabular}

It is evident that the value of $F$ test $(F=.001$ level of significance .975) with the appropriate number of degrees of freedom is not statistically significant at $p<0.05$ in the initial test, which indicates that the groups are uniform in the initial foreknowledge. After the unification of groups, an experimental program was introduced in experimental group, and a multidimensional approach to learning through the integration of mathematics contents with the contents of science \& social studies, while the control group was working as usual. By analyzing the results of the control and experimental groups after the completion of the research, the differences between the groups have been introspected (Table 3). 
IJAEDU- International E-Journal of Advances in Education, Vol. 3, Issue 7, April 2017

Table 3. The results of the experimental and control groups at the final test in Mathematics

\begin{tabular}{|c|c|c|c|c|c|c|c|c|}
\hline \multirow{2}{*}{ Group } & \multirow{2}{*}{$\mathrm{N}$} & \multirow{2}{*}{ Mean } & \multirow{2}{*}{$\begin{array}{l}\text { Std. } \\
\text { Dev. }\end{array}$} & \multirow{2}{*}{$\begin{array}{l}\text { Std. } \\
\text { Er. }\end{array}$} & \multicolumn{2}{|c|}{$\begin{array}{l}95 \% \text { Confidence } \\
\text { Interval for Mean }\end{array}$} & \multirow{2}{*}{ Min. } & \multirow{2}{*}{ Max. } \\
\hline & & & & & $\begin{array}{l}\text { Lower } \\
\text { Bound }\end{array}$ & $\begin{array}{l}\text { Upper } \\
\text { Bound }\end{array}$ & & \\
\hline Experimental & 139 & 8.244 & 1.082 & .091 & 8.063 & 8.426 & 5 & 10 \\
\hline Control & 139 & 7.733 & 1.432 & .121 & 7.493 & 7.974 & 4 & 10 \\
\hline Total & 278 & 7.989 & 1.292 & .077 & 7.836 & 8.141 & 4 & 10 \\
\hline
\end{tabular}

At the final test the students of the experimental group achieved the average of 8.244 , and students of the control group 7.733 points indicating the difference in achievement in favor of the experimental group. From 2221 points, which was the total number of points scored, the students of the experimental group have won in $1146(51.60 \%)$ while the control group of students won $1075(48.40 \%)$ points. The difference of 71 points in favor of the experimental group indicates the positive values of the experimental program. By the analysis of variance of the final test it is verified whether this difference was statistically significant (Table 4).

Table 4. Analysis of variance of the final test in Mathematics

\begin{tabular}{|c|c|c|c|c|c|}
\hline & Sum of Squares & $\mathrm{df}$ & Mean Square & $\mathrm{F}$ & Sig. \\
\hline Between Groups & 18.133 & 1 & 18.133 & 11.251 & .001 \\
\hline Within Groups & 444.835 & 276 & 1.612 & & \\
\hline Total & 462.968 & 277 & & & \\
\hline
\end{tabular}

The value of $F$ test $(F=11.251$ with the level of significance .001$)$ indicates that the difference is statistically significant, which suggests that the adequately selected teaching contents and their effective integration with the teaching of science \& social studies contribute to better knowledge of mathematics compared to the students in control group with the same contents studied in the traditional way. The common theoretical basis of the studied contents, as a basis for the integration, has contributed to the postive results because Science \& Social Studies contents allow contextualization of the mathematical contents and bring them closer to real-life situations that that make abstract concepts more accessible and comprehensible to pupils of lower school age.

Further analysis was carried out in order to determine whether the same effect is achieved in the realization of contents in teaching science \& social studies, since contents in the teaching process are mainly integrated around thematic and content units that basically have the natural and social environment. Before the introduction of the experimental program groups were matched according to the results of the initial test and after completion of the experimental program the results achieved in the experimental and control groups were analyzed (Table 5).

Table 5. The results of the experimental and control groups at the initial and final tests in Science \& Social Studies

\begin{tabular}{|c|c|c|c|c|c|c|c|c|c|}
\hline \multirow[b]{2}{*}{ Test } & \multirow[b]{2}{*}{ Grupa } & \multirow[b]{2}{*}{$\mathrm{N}$} & \multirow[b]{2}{*}{ Mean } & \multirow{2}{*}{$\begin{array}{l}\text { Std. } \\
\text { Dev. }\end{array}$} & \multirow{2}{*}{$\begin{array}{l}\text { Std. } \\
\text { Er. }\end{array}$} & \multicolumn{2}{|c|}{$\begin{array}{l}95 \% \text { Confidence } \\
\text { Interval for Mean }\end{array}$} & \multirow[b]{2}{*}{ Min. } & \multirow[b]{2}{*}{ Max. } \\
\hline & & & & & & $\begin{array}{l}\text { Lower } \\
\text { Bound }\end{array}$ & $\begin{array}{l}\text { Upper } \\
\text { Bound }\end{array}$ & & \\
\hline \multirow[t]{3}{*}{ Initial test } & Experimental & 139 & 7.841 & 1.281 & .108 & 7.626 & 8.056 & 4 & 10 \\
\hline & Control & 139 & 7.848 & 1.273 & .108 & 7.635 & 8.062 & 4 & 10 \\
\hline & Total & 278 & 7.845 & 1.275 & .076 & 7.694 & 7.995 & 4 & 10 \\
\hline \multirow[t]{3}{*}{ Final test } & Experimental & 139 & 8.834 & .921 & .078 & 8.680 & 8.989 & 6 & 10 \\
\hline & Control & 139 & 8.546 & 1.187 & .100 & 8.347 & 8.745 & 5 & 10 \\
\hline & Total & 278 & 8.690 & 1.070 & .064 & 8.564 & 8.817 & 5 & 10 \\
\hline
\end{tabular}


At the initial test in Science \& Social Studies the students of both groups (experimental and control) have achieved an average of 7.84 points which indicates the uniformity of the groups concerning prior knowledge in these areas. In the overall achievement pupils gained 2181 points, the experimental group reached 1090 points and the control group 1091 points. The uniformity of the groups at the initial test in science \& social studies is also indicated by the statistical parameters $(F=.002, p=.963)$ obtained by analysis of variance (Table 6). After the equalization of the groups, the experimental program is being introduced in the experimental group whereas the control group has been working in the usual way, and after the completion of the experiment, we get the results of student achievement. At the beginning, descriptive statistics was calculated (Table 5) indicating the possible difference between the given groups. From a total of 2416 points, the students of the experimental group achieved in 1228 (50.83\%) points, while the students of the control group achieved $1188(49.17 \%)$ points. After examining the results we can see that the students of the experimental group achieved a slightly higher average number of points (8.834) compared to the control group (8.546). The results of student achievement have been checked by the procedure of analysis of variance (Table 6) in order to determine the statistical significance of the differences, or the effects of integrated teaching in learning the contents of science \& social studies.

Table 6. Analysis of variance of the initial and final tests in Science \& Social Studies

\begin{tabular}{|c|c|c|c|c|c|c|}
\hline Test & & Sum of Squares & $\mathrm{df}$ & Mean Square & $\mathrm{F}$ & Sig. \\
\hline Initial test & Between Groups & .004 & 1 & .004 & .002 & .963 \\
\cline { 2 - 7 } & Within Groups & 450.345 & 276 & 1.632 & & \\
\cline { 2 - 7 } & Total & 450.349 & 277 & & & \\
\hline Final test & Between Groups & 5.755 & 1 & 5.755 & 5.097 & .025 \\
\cline { 2 - 7 } & Within Groups & 311.640 & 276 & 1.129 & & \\
\cline { 2 - 8 } & Total & 317.396 & 277 & & & \\
\hline
\end{tabular}

The value of $\mathrm{F}$ test, which amounts to 5.755 and the level of significance .025 confirms that the difference between groups is statistically significant at the level $p<0.05$ suggesting that the experimental program has a more significant effect than the traditional teaching on students' progress in science \& social studies. This means that cross-curricular integration with its multi-perspective, in addition to contributing to the development of mathematical thinking, helps students have the overall experience and understanding of the natural and social environment. By linking similar contents within different subjects, the greater coherence and homogeneity of the acquired knowledge was achieved, that is a prerequisite for lasting knowledge and its rational transfer to real life situations.

In the last step of the analysis the research results we have compared students' achievement in mathematics and science \& social studies based on the results pupils achieved in the knowledge tests (initial and final) within the experimental program (Chart 1). The chart shows the percentage ratio of pupils' achievement in relation to the total number of points that is in all of the tests in each area amounted to 1390. The aim was to comparatively display the results and detect trends of progress in the students' achievement in each of the analyzed areas.

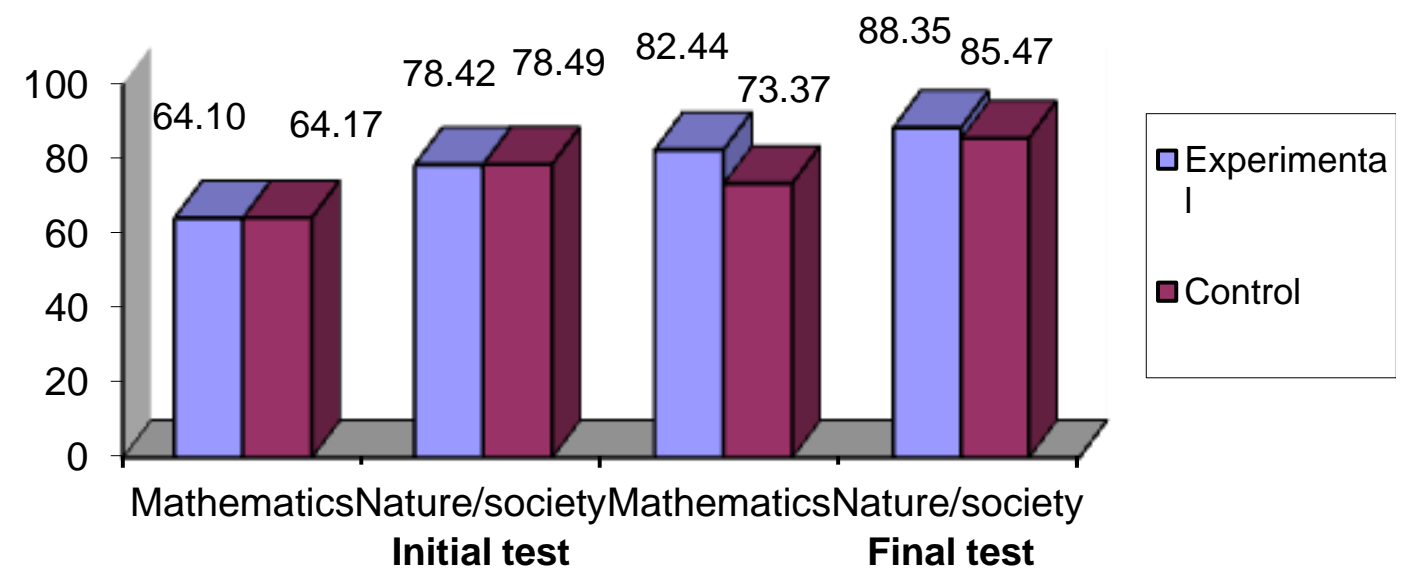

Chart 1. Comparative review of students' achievement in the experimental and control groups at the initial and final knowledge tests 
After examining the empirical parameters we can see that the groups were even at the beginning of the experimental program, but that students in the initial test showed a slightly greater knowledge of Science \& Social Studies, which was to be expected considering the nature and character of the studied subjects. Next, it should be noted that both groups of respondents, compared to the initial testing, have made a progress. However, the experimental group had made a bigger step forward, which can be attributed to the applied experimental program. The results are consistent with similar studies which have shown that the integrative approach increases the quality of functional and applicable knowledge (Kyburz-Graber et all, 2003; Robottom \& Sauvé, 2003; Liarakou \& Flogaitis, 2007; Tsurusaki \& Anderson, 2010; Conde \& Sánchez, 2010; Carrió et all, 2011; according to: Miljanović, 2016, pp. 103-118).

It is particularly important that the trend of progress has been particularly noticed in Mathematics rather than in teaching Science \& Social Studies, since the projected model of integrated teaching contributes to the contextualization of teaching mathematics, which is the key aspect of realistic mathematics education.

During implementation of the experimental program, the large commitment of students, a collaborative spirit and motivation to work and to do school tasks have been observed, which is consistent with numerous other studies (Vars, 1991, pp.14-15; Lake, 1994; Mathison \& Freeman,1997; Klein, 2006, pp.10-18; Ševkušić \& Šefer, 2006, pp. 269-282; Duran, Ballone Duran \& Worch, 2009, pp. 19-29).

\section{CONCLUSION}

Reflections on interdisciplinary educational models in the neighboring area have existed for years, but their application in our conditions still consists of no more than the optimal correlation between subjects. The reason for this is that teaching scenarios based on the integration of educational contents, connecting the individual parts of the curriculum topics in a whole, linking educational contents to the living environment of students; need to be organized more thoroughly, including the separate aspects of a particular subject or science (Terhart, 2001). Numerous studies here and abroad show that the lack of generally accepted models of interdisciplinary teaching in elementary grades is primarily the result of inadequate didactic-methodical and professional competence of teachers and poor communication and lack of time, especially for more complex forms of interdisciplinary connections (Kostović-Vranješ \& Šolić, 2011, pp. 207-216).

The framework of interdisciplinary learning and teaching in elementary grades represents the contents of teaching science \& social studies, which are by their nature integrative. Their main task, as outlined in the syllabus, is that children, gaining knowledge, skills and habits, develop cognitive, physical, social and creative skills, and to simultaneously learn and build attitudes and values of the environment in which they grow up, as well as of the wider community. The subject contents that make up the thematic framework of integrated teaching and the age at which they are intended suggest to the teacher that learning in the basic cycle of elementary school should be organized so that it is some kind of way from emotions to notions. This is especially important when it comes to abstract mathematical concepts. Since mathematics classroom teaching is the basis of organized mathematics education and that the attitudes about math, formed at this stage, follow the child throughout the school, there is the crucial role of a teacher to spark the interest in mathematics in children and to keep it constantly alive (Dejić, 2000). In this sense, the teacher can be "helped" by integrative educational models, in which the central figure is a student and his natural and social environment, i.e. the real context that should be the basis of the working atmosphere in the classroom. It generates a mathematical problem that encourages mathematical activities and practical application of mathematical knowledge.

If we recognize the dynamics, interdisciplinarity and functionality of knowledge as the benefits of integrated teaching on time, we will come to the significant improvements in the teaching process that will prepare pupils to become "productive" members of the society.

\section{REFERENCE LIST}

Banjac, M. (2015). Rad u višerazrednom odjeljenju i maloj seoskoj školi-metodički pristup promjenama. Banja Luka: Grafid d.o.o.

Buljubašić-Kuzmanović, V. (2007). Studentska prosudba učinkovitosti integrativnog učenja, Odgojne znanosti, 9 (2).

Dejić, M. (2000). Metodika nastave matematike (razredna nastava). Jagodina: Učiteljski fakultet. 
Duran, E., Ballone Duran, L., \& Worch, E. A. (2009). Papier-mâché animals: An integrating theme for elementary classrooms. The Science Education Review, 8.

Đorđević, V. (2007). Inovativni modeli nastave (Integrativna nastava, Projektna nastava i Interaktivna nastava), Obrazovna tehnologija, vol. 4.

Žderić, M. \& Miljanović, T. (2001). Metodika nastave biologije. NoviSad: Prirodno-matematički fakultet, Institut za biologiju.

Klein, J. T. (2006). A Platform for a Shared Discourse of Interdisciplinary Education. Journal of Social Science Education, vol. 5 (4).

Kostović-Vranješ, V. \& Šolić, S. (2011). Nastavni sadržaji Prirode i društva - polazište za interdisciplinarno poučavanje u razrednoj nastavi, Život i škola, 25 (1).

Lake, K. (1994): Integrated curriculum, School improvement research series. Portland: Nortwest Regional Educational Laboratory.

Mathison, S., \& Freeman, M. (1997). The logic of interdisciplinary studies. Paper presented at the Annual Meeting of the American Educational Research Association.

Meyer, M. (2007). Increasing the frame: interdisciplinarity, transdisciplinarity and representativity. Interdisciplinary Science Reviews. 32 (3).

Milinković, D. (2012). Integrative Approach to Teaching Mathematics in the Republic of Srpska."Theory and Practice of Connecting and Learning Process", proceedings. Sombor: University of Novi Sad Faculty of Education in Sombor.

Milinković, D. (2013). Interdisciplinarni problemski pristup obradi matematičkih sadržaja u mlađim razredima osnovne škole. Nova škola, VIII (11).

Milinković, D. (2015). Mjesto i uloga kontekstualnih problema u realističkom matematičkom obrazovanju. Nova škola, X (2).

Miljanović, T. (2016). Značaj interdisciplinarnosti u savremenoj nastavi prirodnih nauka. Zbornik radova III Simpozijuma biologa i ekologa Republike Srpske (SBERS 2015), vol. 7 (1).

Radivojević, D. (2014). Modeli aktivnog učenja u diferenciranoj i individualizovanoj nastavi prirode i društva, Nova škola, IX (2).

Ševkušić, S. \& Šefer, J. (2006). Akciono istraživanje novog pristupa nastavi poznavanja društva u četvrtom razredu osnovne škole. Nastava i vaspitanje, 55 (3).

Terhart, E. (2001). Metode poučavanja i učenja. Zagreb: Educa.

Ćurčić, M. (2006). Metodička i organizaciona struktura nastave prirode i društva. Istočno Sarajevo: Zavod za udžbenike i nastavna sredstva.

Vars, G. (1991). Integrated curriculum in historical perspective, Education Leadership, 49 (2).

Walsh, B., K., (2002). Kurikulum za prvi razred osnovne škole: stvaranje razreda usmjerenog na dijete. Zagreb: Pučko otvoreno učilište Korak po korak. 